\title{
Non-enzymatic cyclic oxygenated metabolites of adrenic, docosahexaenoic, eicosapentaenoic and $\alpha$-linolenic acids; bioactivities and potential use as biomarkers ${ }^{\text {is }}$
}

\author{
Jean-Marie Galano ${ }^{\mathrm{a}}$, Jetty Chung-Yung Lee ${ }^{\mathrm{b}}$, Cecile Gladine ${ }^{\mathrm{c}}$, Blandine Comte ${ }^{\mathrm{c}}$, Jean-Yves Le Guennec ${ }^{\mathrm{d}}$, \\ Camille Oger ${ }^{\mathrm{a}}$, Thierry Durand ${ }^{\mathrm{a}, *}$ \\ a Institut des Biomolécules Max Mousseron (IBMM), UMR 5247, CNRS, University Montpellier I and II, ENSCM, Faculty of Pharmacy, Montpellier, France \\ b School of Biological Sciences, The University of Hong Kong, Hong Kong \\ ' INRA, UMR1019, UNH, CRNH Auvergne, Clermont-Ferrand, Clermont Université, Université d'Auvergne, Unité de Nutrition Humaine, Clermont-Ferrand, France \\ d INSERM U1046, Physiologie E' Médecine Expérimentale du Cœur et des Muscles, University Montpellier I and II, Montpellier, France
}

\section{A B S T R A C T}

Cyclic oxygenated metabolites are formed in vivo through non-enzymatic free radical reaction of $n-6$ and n-3 polyunsaturated fatty acids (PUFAs) such as arachidonic (ARA C20:4 n-6), adrenic (AdA 22:4 n-6), $\alpha$-linolenic (ALA 18:3 n-3), eicosapentaenoic (EPA 20:5 n-3) and docosahexaenoic (DHA 22:6 n-3) acids. These cyclic com-pounds are known as isoprostanes, neuroprostanes, dihomo-isoprostanes and phytoprostanes. Evidence has emerged for their use as biomarkers of oxidative stress and, more recently, the n-3PUFA-derived compounds have been shown to mediate bioactivities as secondary messengers. Accordingly, this review will focus on the cy-clic oxygenated metabolites generated from AdA, ALA, EPA and DHA. This article is part of a Special Issue entitled "Oxygenated metabolism of PUFA: analysis and biological relevance".

Keywords:

Phytoprostanes

Dihomo-isoprostanes

Neuroprostanes

Isofurans

Biomarkers

Bioactive lipids

\section{Introduction}

Free radicals are implicated in a wide variety of human diseases [1] and the consequences are the oxidation of biomolecules, including DNA, proteins and lipids. Among lipids, polyunsaturated fatty acids (PUFAs) have reactive skipped dienes, or methylated interrupted double bonds, that can participate to form acyclic, and subsequently, stable cyclic oxygenated metabolites [2]. Since the discovery of $\mathrm{F}_{2}$-isoprostanes ( $\mathrm{F}_{2}$-IsoPs) by Morrow et al. in 1990 derived from arachidonic acid (ARA, 20:4 n-6) peroxidation in vivo [3], an important field of research has been developed. Nowadays, elevation of $\mathrm{F}_{2}$-IsoP levels in biological fluids (e.g. plasma and urines) is recognized as the reference biomarker for lipid peroxidation and oxidative stress [4]. Because of the high reactivity and short life span of free radicals, oxidative stress is evaluated by the measurement of damaged biological products, which can be considered as biomarkers of lipid peroxidation. Beyond their capacity of oxidative stress evaluation, isoprostanes also demonstrate to be biologically active $[2,5,6]$.

\footnotetext{
This article is part of a Special Issue entitled "Oxygenated metabolism of PUFA: Analysis and biological relevance".

* Corresponding author.
}

Docosahexaenoic (DHA, 22:6 n-3) and eicosapentaenoic (EPA, 20:5 $\mathrm{n}-3$ ) acids, the main n-3 PUFAs, form neuroprostanes (NeuroPs) $[7,8]$ and EPA-derived isoprostanes [9], respectively, under free radical reactions. Also, the n-6 PUFA adrenic acid (AdA, 22:4) located in brain white matter and other tissues, such as the adrenal gland and kidney, is the precursor of dihomo-isoprostanes (dihomo-IsoPs) [10]. Finally $\alpha$-linolenic acid (ALA, 18:3 n-3) from plants may be converted into phytoprostanes (PhytoPs) [11].

This review will focus on the isoprostanes, neuroprostanes, dihomoisoprostanes and phytoprostanes generated from ALA, AdA, EPA and DHA with regard to (i) the synthesis of these new cyclic oxygenated metabolites of PUFA, (ii) the use of such lipid metabolites as biomarkers of oxidative stress in humans, and (iii) data relative to their biological activities in vitro and in vivo.

\section{Biosynthesis of cyclic oxygenated metabolites of PUFA}

In 1990, Roberts, Morrow and co-workers discovered novel prostaglandin (PG)-like isomers, which are named isoprostanes. In contrast to PG produced by cyclooxygenases, the mechanism of formation proceeds via a non-enzymatic free radical peroxidation of ARA esterified in phospholipids and not from free ARA [3]. The main structural characteristics compared to PGs are the cis-relationship of the side chains, the 
large number of potential isomers and the generation of racemic metabolites [12,13]. Once formed, the isoprostanes can then be released by phospholipases in the circulating fluids [14] (Scheme 1). Later, it was uncovered that PUFAs such as ALA, EPA, AdA and DHA having at least two-skipped diene units, i.e. three consecutive methylene interrupted units, can form isoprostane-like structures [2] (Scheme 2). In plants, ALA can generate PhytoPs [11] which were originally named dinorIsoPs. DHA and EPA, the main n-3 PUFAs found in humans, release NeuroPs $[7,8]$ and isoprostanes respectively, when subjected to free radical reactions [9]. Another important n-6 PUFA, AdA, highly present in brain white matter, is known to generate dihomo-IsoPs [10].

Similar to the biosynthesis of PGs, the intermediate G-IsoPs can lead to numerous types of IsoPs. Besides the F-type, E-, D-, A-, B-, and L-types (see ref. [2]) of IsoPs, PhytoPs and NeuroPs are also formed in vivo depending on the surrounding conditions of the membrane phospholipids (Scheme 3) [2].

In 2002, a completely novel structure of compounds was uncovered that follows the same free radical cascade pathway of IsoPs. The addition of molecular oxygen after initial cyclization leads to the generation of isofurans (IsoFs) from ARA [15]. It was shown that IsoF levels augment in elevated oxygen conditions (above 21\%) while not so for IsoPs. Similar mechanisms are proposed to access such biosynthesis [2], including neurofurans (Scheme 4) [16,17] (NeuroFs) and dihomoIsofurans [18] (dihomo-IsoFs) from DHA and AdA respectively.

\section{Chemical synthesis of cyclic oxygenated metabolites}

The total synthesis of cyclic oxygenated metabolites is of greatest importance for the general understanding of their in vivo formation and biological functions, but also to explore their potential diagnostic applications. Different strategies to produce PhytoPs, IsoPs, dihomoIsoPs and NeuroPs have been reported in the literature by organic chemists around the world (see few reviews $[2,19,20]$ ). All these strategies developed so far confirmed the biological importance of IsoPs, NeuroPs, and recently PhytoPs, and potential applications as biomarkers of oxidative stress in vivo. Lately, the successful synthesis of dihomoisofuran compounds did uncover their potential as novel oxidative stress biomarkers [18].

\section{Cyclic oxygenated metabolites as biomarkers of lipid peroxidation}

\subsection{Eicosapentaenoic and docosahexaenoic acids}

Among the identified n-3 fatty acids, EPA and DHA are the most notable ones for (patho)physiological functions. They are present in all human tissues at different levels, and DHA is foremost concentrated in the retina and brain. The structural occurrence of multiple double bonds allows the generation of oxygenated metabolites in the presence of free radicals. Oxidation of EPA can generate 6 series of $F_{3}$-IsoPs, of which 96 racemic derivatives can be potentially measured in vivo (see above Scheme 1 for details) [9]. From DHA, a total of 128 theoretical compounds can be formed at basal oxygen level in vivo and these are categorized into 8 regioisomer series $(4,7,10,11,13,14,17$ or 20$)$ of NeuroPs, in which levels of 4 - and 20 -series are eminently high in vivo compared to the 6 other series $[8,21]$. The ratio between the type of oxygenated metabolites generated can also differ according to oxygen concentration, i.e. under hyperoxia NeuroFs are predominant over NeuroPs simply because of the differences in biosynthesis pathways (see above). At this stage, a total of 516 compounds of two families, each comprising 8 regioisomers, can be present in vivo [17].

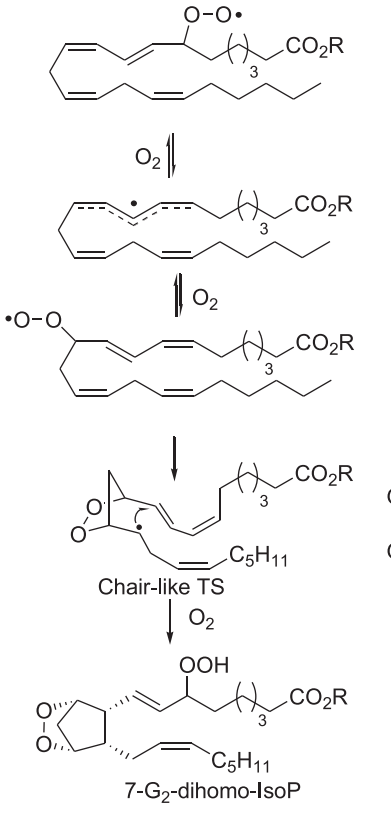

$\downarrow[H]$ and phospholipases
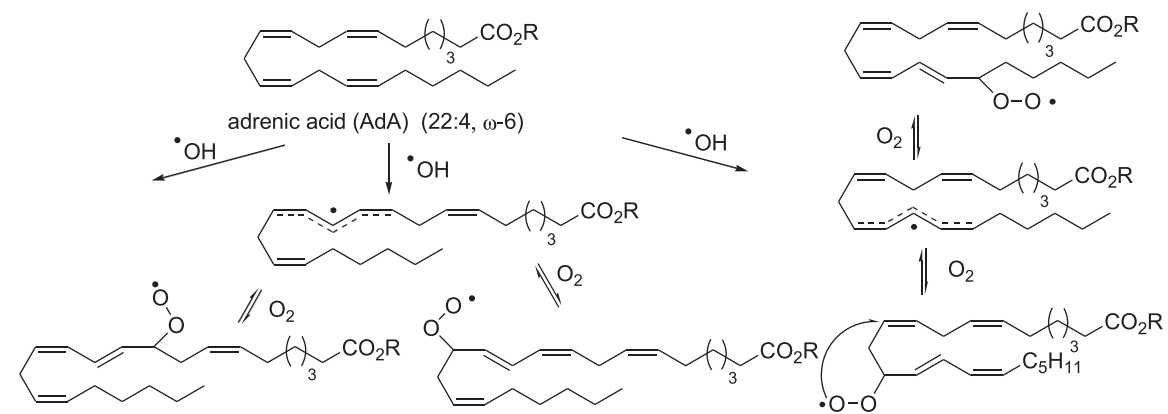

$\downarrow$

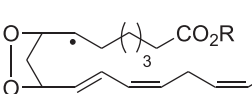

$\downarrow \mathrm{O}_{2}$

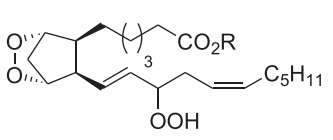

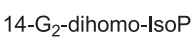

$\downarrow[H]$ and phospholipases

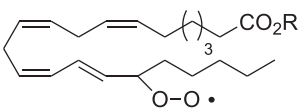

$\mathrm{O}_{2} \|$

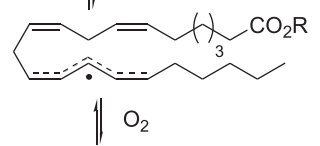

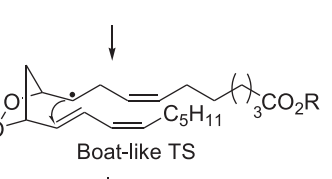

$\downarrow \mathrm{O}_{2}$

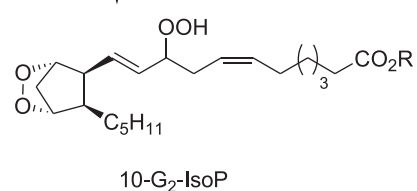

$\sqrt{ }[\mathrm{H}]$ and phospholipases

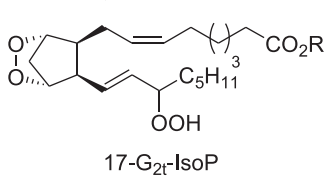

$\downarrow[H]$ and phospholipases
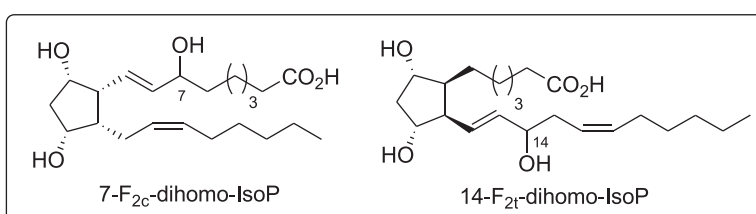

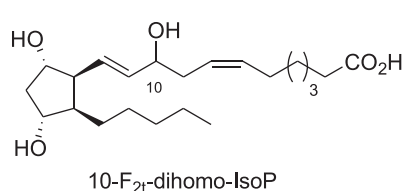

10-F 2t $^{\text {-dihomo-IsoP }}$

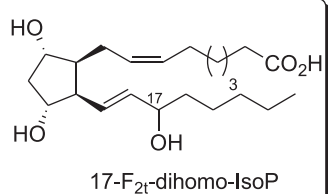

$\mathrm{HO}$

17- $\mathrm{F}_{2 \mathrm{t}}$-dihomo-IsoP

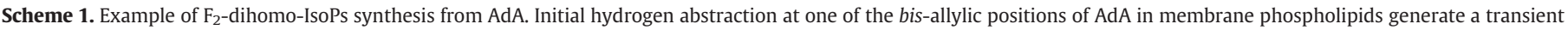

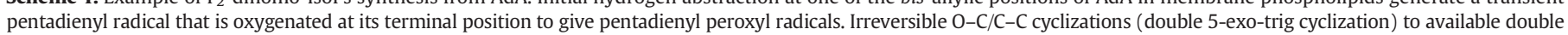
bonds followed by the addition of oxygen and H-transfer yield G-type dihomo-IsoPs. Reduction of the hydroperoxide group then follows to produce the final products. 
<smiles>CC/C=C\CCC/C=C\C/C=C\C/C=C\CCC(=O)O</smiles>

Eicosapentaenoic Acid (EPA)<smiles>CC/C=C\CC/C=C\C/C=C\C/C=C\C/C=C\CC=CCC(=O)O</smiles>

Docosahexaenoic Acid (DHA)<smiles>CCCCCCCCCC=CCC=CCC=CCC=CCC=CCCCC(=O)O</smiles>
Adrenic Acid (AdA)<smiles>CC/C=C/C/C=C\CCCCCCC(=O)O</smiles>

alpha Linolenic Acid (ALA)
ROS<smiles>CCC=CCC=CC[C@H]1CCC(O)[C@@H]1C=C[C@@H](O)CCCC(=O)O</smiles>

$F_{3}$-Isoprostanes<smiles>CC/C=C/C/C=C/C/C=C/C1CCCC1/C=C/[C@H](O)CCC(=O)O</smiles>

$F_{4}$-Neuroprostanes<smiles>CCCCC/C=C/C[C@H]1CCC(O)[C@@H]1/C=C/[C@H](O)CCCCCC(=O)O</smiles>

$\mathbf{F}_{2}$-dihomo-Isoprostanes

HO,<smiles>[R20]SOS(=O)(=O)O</smiles>

$F_{1}$-Phytoprostanes

\section{ROS : Reactive Oxygen Species}

Scheme 2. Summary of the biosynthesis of $F_{1}$-PhytoPs, $F_{3}$-IsoPs, $F_{2}$-Dihomo-IsoPs, and $F_{4}$-NeuroPs from their respective PUFA precursors.

DHA is the main n-3 PUFA in vivo and is highly concentrated in the brain. It exists in the fetus through the maternal diet whereas it almost exclusively comes from food in humans. It is amenable to explore the role of NeuroPs and NeuroFs in the brain, however they were recently found to have multiple roles in other parts of the body, including the heart. Nevertheless, there is a smaller number of reports on NeuroPs and NeuroFs compared to IsoPs. To date, there is only a small number of synthetic standards that can be used for either gas chromatographymass spectrometry (GC-NICI-MS or GC-NICI-MS/MS) or liquid chromatography coupled to tandem mass spectrometry (LC-MS/MS) (Table 1) [22].

\subsection{1. $F_{3}$-Isoprostanes as oxidative stress biomarkers}

The level of $\mathrm{F}_{3}$-isoprostanes ( $\mathrm{F}_{3}$-IsoPs) is a reliable index of specific lipid peroxidation of EPA and could be considered for an evaluation of oxidative stress in biological systems. In comparison to other biomarkers, they are chemically stable but there is still a lack of knowledge to appreciate them as such. Only recently that biological roles of $\mathrm{F}_{3}$-IsoPs started to be investigated. In humans, stimulation of inflammation by injection of bacterial lipopolysaccharide (LPS) to healthy volunteers augmented urinary $\mathrm{F}_{3}$-IsoPs within 4-6 h and an intravenous injection to mice showed no effect on systemic arterial pressure [23]. In dietary study, supplementation of fish oil to mice increased urinary $\mathrm{F}_{3}$-IsoPs [23] and in LDLR $^{-1-}$ mice, it was found that western diet supplemented with EPA and/or DHA to reduce non-alcoholic steato-hepatitis (NASH) also increased urinary $\mathrm{F}_{3}$-IsoPs as compared to controls [24]. Other investigations showed the acute exposure of fish to hydrogen peroxide increased $\mathrm{F}_{3}$-IsoPs in muscles when compared to controls [25]. $\mathrm{F}_{3}$-IsoPs were also assessed in invertebrates such as Caenorhabditis elegans in different environments, i.e. oxidative and aging conditions. In the report, whole organism including mitochondria and peroxisomes were measured, and $\mathrm{F}_{3}$-IsoPs were shown to be elevated in conditions with mutated mitochondrial electron transport proteins, and in aged nematodes compared to young ones [26]. At cellular level, $\mathrm{F}_{3}$-IsoPs were also measured in Jurkat cells to evaluate the physical effect of microbubbles during sonoporation, and it was shown to be elevated when compared to non-treated cells [27].

\subsubsection{Neuroprostanes and neurofurans as oxidative stress biomarkers}

The measurement of $\mathrm{F}_{4}$-NeuroPs was initially performed in animals, such as normal rat and newborn pig brains, and the level was considerably higher in the cortex of the newborn pig brain [8]. Thereafter, $\mathrm{F}_{4^{-}}$ NeuroPs were identified, in particular occipital and temporal lobes of brain tissues of Alzheimer's disease (AD) patients [28], and also in cerebrospinal fluid (CSF) of aneurismal subarachnoid hemorrhage patients. It was found to be nearly two-fold and ten-fold higher, respectively, compared to controls $[8,29]$. These findings opened a new area of research in neurodegenerative diseases as the involvement of reactive oxygen species (ROS) and oxidative stress is highly hypothesized in their developments. Thereafter, most of the observational studies (Table 1) focused on brain tissues of patients of periventricular white matter injury, mild cognitive impairment and in late stage of $\mathrm{AD}$, transgenic mice, and in rare disease models such as Smith-Lemli-Opitz syndrome [17,30-33]. It was recently reported that, in Mecp2 mutant mouse models of Rett syndrome (RTT), the brain concentration of $\mathrm{F}_{4}$-NeuroPs is elevated in symptomatic and pre-symptomatic phases, in which the latter can lead to the onset of overt behavioral abnormalities. Moreover, Mecp2-null animals had inversed relationships between $\mathrm{F}_{4}$-NeuroPs 


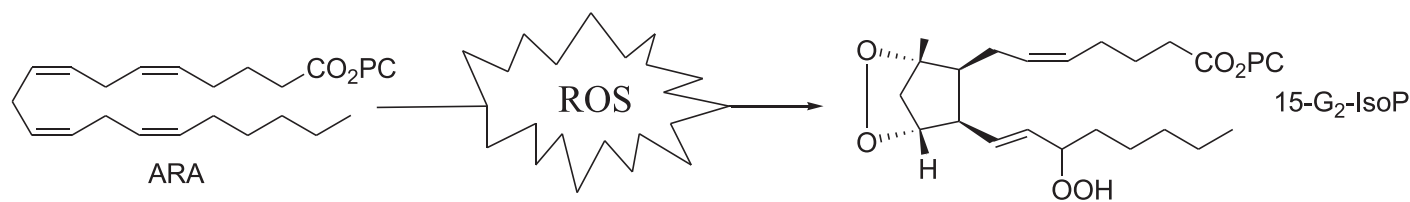

High local concentration of

Glutathione (GSH) $\alpha$-tocopherol

Reductive O-O Bond

Cleavage
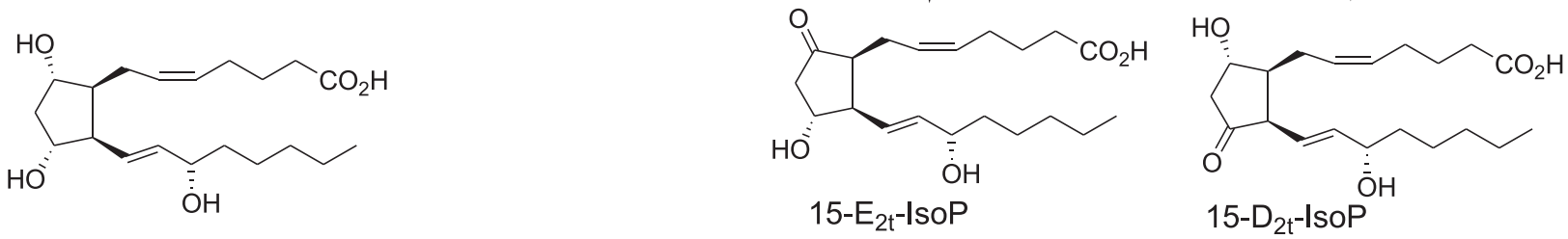

$15-\mathrm{F}_{2 \mathrm{t}}$-IsoP
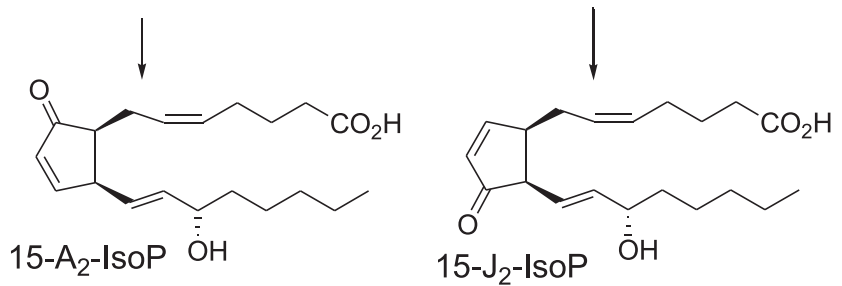

Scheme 3. Generation of substituted isoprostanes through stabilization of $\mathrm{G}_{2}$-IsoPs.
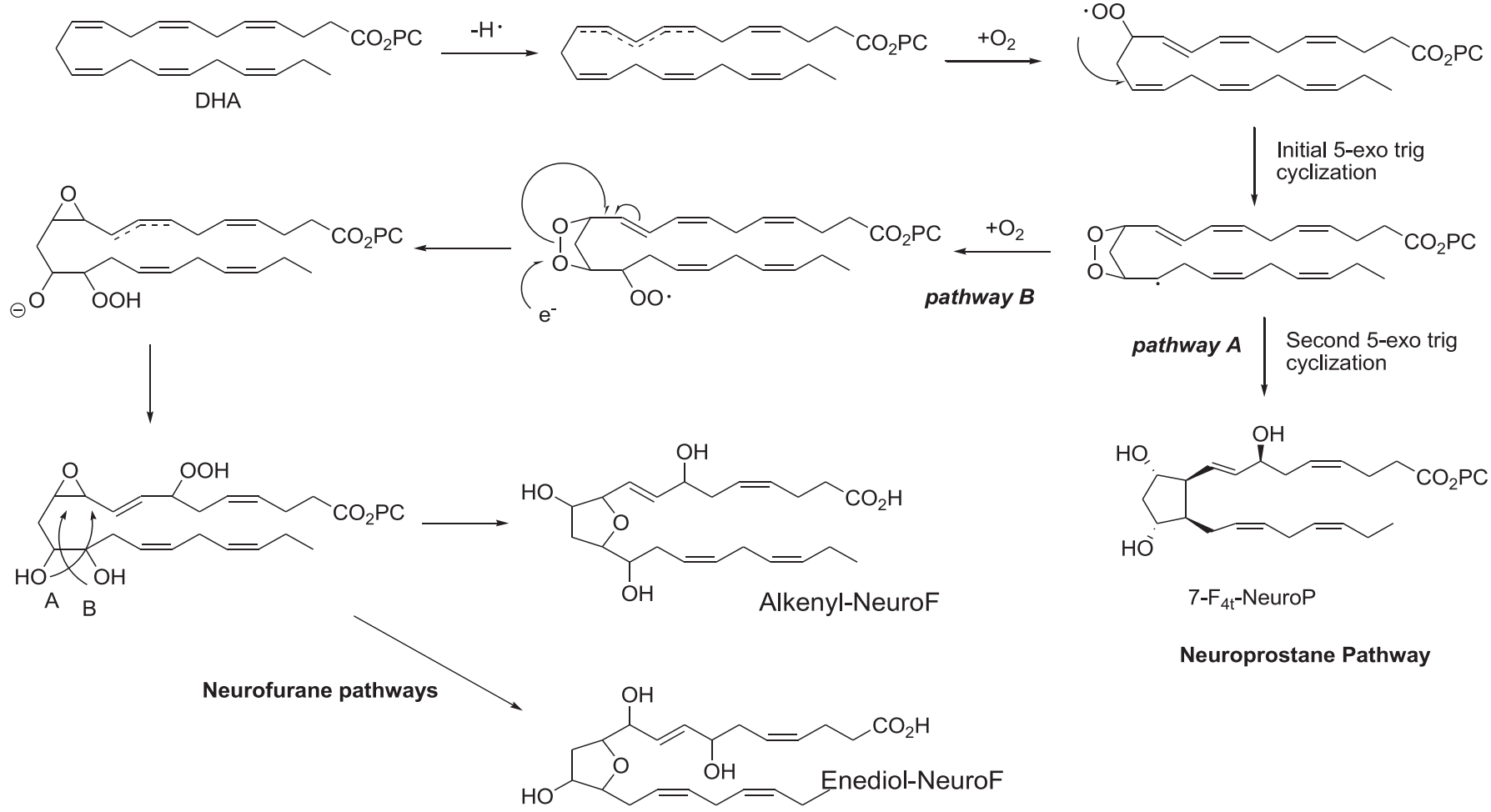

Neuroprostane Pathway

Scheme 4. Summary biosynthetic pathway of neurofuran DHA. 
Table 1

Summary of observational studies reporting levels of neuroprostanes and neurofurans.

\begin{tabular}{|c|c|c|c|c|}
\hline Model of study & Sample & Metabolites measured & $\begin{array}{l}\text { Method of } \\
\text { measurement }\end{array}$ & Reference \\
\hline \multicolumn{5}{|l|}{ Human } \\
\hline $\begin{array}{l}\text { Smokers and age-matched controls; Ischemic-stroke patients } \\
\text { and age-matched controls }\end{array}$ & Plasma & $\mathrm{F}_{4}$-NeuroPs & GC-NICI-MS & {$[38,39]$} \\
\hline Pre-eclampsia patients and normal pregnant women & Plasma of maternal and umbilical cord blood & $\mathrm{F}_{4}$-NeuroPs & GC-NICI-MS & {$[40]$} \\
\hline High cardiovascular risk subjects & Plasma & $\mathrm{F}_{4}$-NeuroPs & GC-NICI-MS & $\begin{array}{l}\text { Seet et al. } \\
(2013)\end{array}$ \\
\hline $\begin{array}{l}\text { Adolescent Rett Syndrome patients and age-and } \\
\text { gender-matched healthy controls }\end{array}$ & Plasma & $\mathrm{F}_{4}$-NeuroPs & GC-NICI-MS/MS & [37] \\
\hline Influenza A patients and age-matched controls & Plasma & $\mathrm{F}_{4}$-NeuroPs & GC-NICI-MS & {$[41]$} \\
\hline PD patients and age-matched healthy controls & Plasma & $\mathrm{F}_{4}$-NeuroPs & GC-NICI-MS & [36] \\
\hline Healthy subjects & Urine & 7-F $\mathrm{Fc}_{4 \mathrm{c}}-\mathrm{NeuroP}$ & $\begin{array}{l}\text { GC-NICI-MS } \\
\text { LC-MS/MS }\end{array}$ & {$[88]$} \\
\hline Non-aSAH control patients and aSAH patients & CSF & $\mathrm{F}_{4}$-NeuroPs & GC-NICI-MS & [29] \\
\hline $\begin{array}{l}\text { Patients with severe aSAH and TBI, and age-and } \\
\text { gender-matched healthy controls }\end{array}$ & CSF & $4(R S)-\mathrm{F}_{4 \mathrm{t}}-$ NeuroP & GC-NICI-MS & [89] \\
\hline Normal and patients with aSAH & CSF & $\mathrm{F}_{4}$-NeuroPs & GC-NICI-MS & [90] \\
\hline $\mathrm{AD}$ and healthy controls & Brain: Occipital, temporal and parietal lobes & $\mathrm{F}_{4}$-NeuroPs & GC-NICI-MS & [28] \\
\hline AD patients and age- and gender-matched healthy controls & $\begin{array}{l}\text { Post-mortem brain samples: superior and middle } \\
\text { temporal gyri, hippocampus, inferior parietal } \\
\text { lobule and cerebellar cortex }\end{array}$ & $\begin{array}{l}\text { Total }\left(\mathrm{D}_{2} / \mathrm{E}_{2} \text {-IsoPs }+\right. \\
\left.\mathrm{D}_{4} / \mathrm{E}_{4} \text {-NPs }\right) \\
\mathrm{F}_{4} \text {-NeuroPs }\end{array}$ & GC-NICI-MS & [30] \\
\hline Early PWMI and age-matched controls & Post-mortem brain samples & $\mathrm{F}_{4}$-NeuroPs & GC-NICI-MS & [31] \\
\hline Healthy control, $\mathrm{MCI}$, and late $\mathrm{AD}$ patients & $\begin{array}{l}\text { Post-mortem brain samples of: frontal and occipital } \\
\text { lobes, inferior parietal lobule, and hippocampus }\end{array}$ & $\mathrm{F}_{4}$-NeuroPs & GC-NICI-MS & {$[91]$} \\
\hline \multicolumn{5}{|l|}{ Animals } \\
\hline $\mathrm{AD}$ and age-matched control; rats; newborn pigs & CSF, whole rat brain, brain cortex of newborn pig & $\mathrm{F}_{4}$-NeuroPs & GC-NICI-MS & {$[8]$} \\
\hline Fischer 344 rats & Young and old brains & $\mathrm{F}_{4}$-NeuroPs & GC-NICI-MS & $\begin{array}{l}\text { Youssef et al. } \\
(2003)\end{array}$ \\
\hline Tg 2576 mice: Transgenic mice model of AD & Brain cortex & $\begin{array}{l}\mathrm{F}_{4} \text {-NeuroPs } \\
\text { NeuroFs }\end{array}$ & $\begin{array}{l}\text { GC-NICI-MS } \\
\text { LC-MS/MS }\end{array}$ & [17] \\
\hline Newborn pigs & Brain prefrontal cortex & $\begin{array}{l}\mathrm{F}_{4} \text {-NeuroPs } \\
\text { NeuroFs }\end{array}$ & GC-NICI-MS & [35] \\
\hline $\begin{array}{l}\text { Dhcr7-KO Mice Dhcr7-KO (Dhcr7 }{ }^{\text {tm1Gst/J }} \text { ): genetic mouse model } \\
\text { of Smith-Lemli-Opitz syndrome }\end{array}$ & Brain and liver & $\mathrm{F}_{4}$-NeuroPs & GC-NICI-MS & [33] \\
\hline Preterm pigs & Brain prefrontal and medial prefrontal cortex & $\begin{array}{l}\mathrm{F}_{4} \text {-NeuroPs } \\
\text { NeuroFs }\end{array}$ & LC-MS/MS & [18] \\
\hline $\begin{array}{l}\text { Mecp2 mutant mouse models of Rett Syndrome including } \\
\text { Mecp2-null (pre-symptomatic, symptomatic, and rescued) } \\
\text { and Mecp2-308 mutated (pre-symptomatic and symptomatic) } \\
\text { mice and wild type littermates }\end{array}$ & Plasma and brain & $\mathrm{F}_{4}$-NeuroPs & GC-NICI-MS/MS & [34] \\
\hline
\end{tabular}

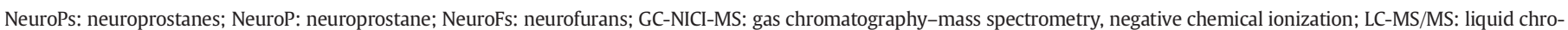

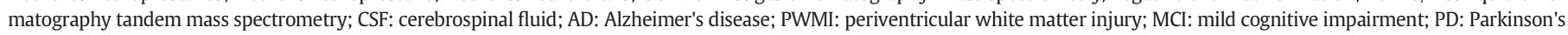
disease; aSAH: aneurysmal subarachnoid hemorrhage; TBI: traumatic brain injury.

levels and brain weight and body weights [34]. RTT is a known neurodevelopment disorder by loss of function due to mutation in the gene encoding the methyl-CpG binding protein 2 (MECP2), and considered as a genetic model of infantile autism in female.

In a recent study, two specific regioisomers of $\mathrm{F}_{4}$-NeuroPs, 4(RS)-4$\mathrm{F}_{4 \mathrm{t}}$-NeuroP and $10-\mathrm{F}_{4 \mathrm{t}}$-NeuroP, were quantified in brain prefrontal and medial prefrontal cortex of preterm pigs and it was found that $4(R S)$ $4-\mathrm{F}_{4 \mathrm{t}}$-NeuroP was predominant, indicating that not all types of NeuroPs may be actively released under oxidative stress conditions. Not many data (Table 1) are yet available on NeuroFs. A quantitative method was recently developed [16], and NeuroFs were measured in the brain cortex and cerebellum of $\mathrm{AD}$ transgenic mice and reported to be predominant in the cortex [17]. An increase in oxygen tension to $>21 \%$ in newborn pigs has been shown to substantially increase levels of NeuroFs in the brain prefrontal cortex [35].

Evaluation in brain tissues in humans and rodents revealed $\mathrm{F}_{4}$-NeuroPs to be a valuable biomarker of neuronal disorders. Similar findings were found in plasma of Parkinson's disease patients. Seet et al. [36] have shown that $\mathrm{F}_{4}$-NeuroP plasma levels of Parkinson's disease patients were elevated when compared to controls and were independent of the severity of the disease. In addition, plasma of adolescent RTT patients had increased levels of free $\mathrm{F}_{4}$-NeuroPs in comparison with healthy controls, and the levels correlated with the severity of the illness [37]. Aside from neurodegenerative diseases, onset of ischemic-stroke also showed to be associated with augmented plasma concentrations of free and esterified $\mathrm{F}_{4}$-NeuroPs, and the levels remained high after the onset, especially for the free form [38]. Levels of $\mathrm{F}_{4}$-NeuroPs were also investigated in cigarette smokers who had augmented plasma concentrations in comparison to controls. The concentration was further elevated in the smokers immediately after cigarette smoking session [39]. Furthermore, plasma of maternal and cord blood of pre-eclampsia women had higher $\mathrm{F}_{4}$-NeuroPs levels compared to normal pregnant women [40]. Nevertheless, not all observational studies showed elevated in vivo $\mathrm{F}_{4}$-NeuroPs levels; it was suppressed in plasma of patients with influenza A, and remained lower than in controls at 3 months post-infection [41]. In cells, the effect of sonoporation in Jurkat cells showed no difference in $\mathrm{F}_{4}$-NeuroPs concentrations when compared to non-treated cells [27].

\subsubsection{Neuroprostanes and neurofurans as biomarkers in metabolic studies}

Intervention studies on NeuroPs were mainly conducted on analyses of their effects on specific areas of rodent brain and rare diseases (Table 2). Studies were highly focused on the effect of antiinflammatory and antioxidant agents in brain upon injury by chemical adulteration, and viral or bacterial infections. Both types of agents showed to be effective in reducing $\mathrm{F}_{4}$-NeuroPs levels after injury, in particular in the cerebrum [42-45]. Levels of $\mathrm{F}_{4}$-NeuroPs in ischemicinduced rodent brain (cerebral cortex, hippocampus, gray matter) were also determined after $\alpha$-lipoic acid treatment but no significant effect was found [46]. However, treatment with melatonin after brain 


Model of study and type of samples $\quad$ Treatment

\section{Human}

Type 2 diabetic patients and age matched controls: plasma Zinc supplementation

Adolescent Rett Syndrome patients: plasma

Young children of Rett Syndrome patients: plasma

Zinc supplementatio
$\omega-3$ PUFA (fish oil)

Adolescent Rett Syndrome patients: plasma

$\omega-3$ PUFA (fish oil)

$\omega-3$ PUFA (fish oil)

Sprague-Dawley: cerebrum, plasma and urine

Sprague-Dawley: brain

Sprague-Dawley: brain

Ischemia-induced Sprague-Dawley: brain ipsilateral striatum, ipsilateral cortex, contralateral striatum, and contralateral cortex

Wistar: brain

Hypoxia-ischemia induced Sprague-Dawley:

brain, prefrontal cortex

Mice

C57BL/6: cerebrum

C57BL/6: cerebrum

ATM $-/-$ and ATM $+/+$ : forebrain and cerebellum

BALB/c: brain

TTg2576: left forebrain cerebral cortex, hippocampus, and deep gray matter

C57B6J: brain cortex and cerebellum

L-gulono- $\gamma$-lactone oxidase (C57BL/6J): brain, medial cortex and cerebellum

APPS $_{\text {we }} /$ PSEN1 $\triangle$ E9 bigenic: cortical tissues

$\operatorname{Tg} 2576$, transgenic mice model of AD: liver samples

Atherosclerosis $\left(L D L R^{-/-}\right)$: liver samples
Subcutaneous injection of KA

Ethanol withdrawal

Carbonfuran with/without memantine $\mathrm{HCl}$ and atropine sulfate

Treatment with or without tamoxifen

Manganese chloride

Melatonin

Pre-treated with indomethacin and ibuprofen for 2 weeks and then ICV injection with KA or LPS

1. ICV LPS with or without N-tert-butyl- $\alpha-$ phenylnitrone and NSAIDs

2. ICV LPS with or without $\alpha$-tocopherol or $\gamma$-tocopherol

3. ICV kainic acid with or without $\alpha$-tocopherol, $\mathrm{N}$-tert-butyl-a-phenylnitrone, or ibuprofen Supplemiton weight salen-manganese for 84 days.

Intracerebral inoculation of either herpes simplex

virus type 1 or normal saline into the left

cerebral hemisphere

$\alpha$-Lipoic acid supplementation. $\quad \mathrm{F}_{4}$-NeuroPs

Induced vitamin E deficiency

$\mathrm{F}_{4}$-NeuroPs

Low and high dose of ascorbic acid supplementation $\mathrm{F}_{4}$-NeuroPs

Low vitamins $\mathrm{C}$ and $\mathrm{E}$, and high vitamins $\mathrm{C}$ and $\mathrm{E} \quad \mathrm{F}_{4}$-NeuroPs

supplementation

$\mathrm{F}_{4}$-NeuroPs

NeuroFs

DHA

$\mathrm{F}_{4}$-NeuroPs

$\mathrm{F}_{4}$-NeuroPs

$\mathrm{F}_{4}$-NeuroPs

$\mathrm{F}_{4}$-NeuroPs

NeuroFs

$\mathrm{F}_{4}$-NeuroPs

-NeuroPs

euroFs

NeuroPs
$\mathrm{F}_{4}$-NeuroPs

$\mathrm{F}_{4}$-NeuroPs

$\mathrm{F}_{4}$-NeuroPs

$\mathrm{F}_{4}$-NeuroPs

$\mathrm{F}_{4}$-NeuroPs

$\mathrm{F}_{4}$-NeuroPs

$\mathrm{F}_{4}$-NeuroPs

-NeuroPs

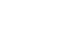

(n)

Lower $\alpha$-tocopherol levels were associated with lower $\mathrm{F}_{4}$-NeuroPs. Low $L$-gulono- $\gamma$-lactone oxidase mice with low ascorbic acid L-gulono- $\gamma$-lactone oxidase mice with high ascorbic acid and wild type.

Treatment of low vitamins $\mathrm{C}$ and $\mathrm{E}$ but not high vitamins $\mathrm{C}$ and

$\mathrm{E}$ reduced $\mathrm{F}_{4}$-NeuroPs compared to control.

Carbon tetrachloride injection increased $\mathrm{F}_{4}$-NeuroPs after $1 \mathrm{~h}$ and after $2.5 \mathrm{~h}$ for NeuroFs compared to controls.

Supplementation of DHA increased $\mathrm{F}_{4}$-NeuroPs in dose-dependent manner. This increase had inverse relationship with risk of atherosclerosis.

$\mathrm{F}_{4}$-NeuroPs elevated after $2 \mathrm{~h}$ and $6 \mathrm{~h}$ exposure in male and female

medaka respectively. decreased free $\mathrm{F}_{4}$-NeuroPs and was inversely

Only, cerebrum $\mathrm{F}_{4}$-NeuroPs elevated $2 \mathrm{~h}$ post $\mathrm{KA}$ treatment.

$\mathrm{F}_{4}$-NeuroPs decreased on both side of prefrontal cortex and

政

Elevated $\mathrm{F}_{4}$-NeuroPs by LPS reduced by $\alpha$-tocopherol or $\gamma$-tocopherol.

Both $\mathrm{F}_{4}$-NeuroPs and NeuroFs decreased after supplementation

compared to placebo but was statistically significant for NeuroFs only

$\mathrm{F}_{4}$-NeuroPs
Reference $\begin{array}{ll}\text { Supplementation of } \omega-3 \text { PUFA for } 6 \text { months decreased free } \mathrm{F}_{4} \text {-NeuroPs } & {[60]} \\ \text { Supplementation of } \omega \text {-3 PUFA for } 6 \text { and } 12 \text { months } & {[80]}\end{array}$

-NeuroPs elevated after KA and LPS exposure, the latter had higher increase.

Fish

Hydrogen peroxide

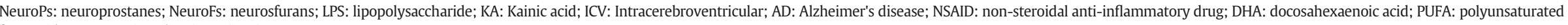
fatty acid; ATM: ataxia-telangiectasia mice. 
ischemic injury reduced concentrations of $\mathrm{F}_{4}$-NeuroPs in both sides of prefrontal cortex, and particularly NeuroFs in the right side [47]. Likewise, tamoxifen also lowered $\mathrm{F}_{4}$-NeuroPs in brain striatum and cortex of ischemic-induced rodent brain [48]. Supplementation of Ataxiatelangiectasia ${ }^{-}-{ }^{-}$mice with salen-manganese (catalytic scavenger of hydrogen peroxide and cytoprotective agent) was able to reduce both levels of $\mathrm{F}_{4}$-NeuroPs and NeuroFs in the forebrain and cerebellum, with a stronger effect on NeuroFs. Ataxia-telangiectasia also known as Louis-Bar Syndrome, is a recessive disease that can lead to cerebellar degeneration and genomic instability as well as suppression of immune functions [49]. Such findings are important in alleviating oxidative stress role in neurological diseases related to brain prefrontal cortex, as it has been associated with bipolar disorders and schizophrenia, and to cognitive dysfunction $[50,51]$.

In the transgenic mice model of $\mathrm{AD}$ ( $\operatorname{~g~2576),~the~injection~of~carbon~}$ tetrachloride $\left(\mathrm{CCl}_{4}\right)$, a strong inducer of lipid peroxidation, raised levels of $\mathrm{F}_{4}$-NeuroPs and NeuroFs in the liver with a peak at $1 \mathrm{~h}$ and $2.5 \mathrm{~h}$ [17]. This is comparable to data reported by Morrow et al. [52] on $\mathrm{F}_{2}$-IsoPs, showing a raise in liver, $2 \mathrm{~h}$ after an oral administration of $\mathrm{CCl}_{4}$. Regardless of the type of rodent used in the model, it appears that the generation of $\mathrm{F}_{4}$-NeuroPs and NeuroFs is rapid, like for $\mathrm{F}_{2}$-IsoPs. Gladine et al. showed that liver samples of $\mathrm{LDLR}^{-1-}$ mice supplemented with different doses of DHA had increased $\mathrm{F}_{4}$-NeuroP levels in a dose-dependent manner. The increase correlated with reduced plaque formation and atherosclerotic lesions, strongly suggesting that $\mathrm{F}_{4}$-NeuroPs might play an active role in atherosclerosis prevention [53].

Aside from the brain and liver, $\mathrm{F}_{4}$-NeuroPs levels were measured in plasma of type 2 diabetic patients, before and after zinc supplementation and no significant change was observed [54]. The effect of hydrogen peroxide on these compounds was recently evaluated in marine fish, showing a rate of increase in $\mathrm{F}_{4}$-NeuroPs levels faster in males than in females [25].

\subsection{Adrenic acid}

AdA is the third most important PUFA in the brain, after DHA and ARA, and particularly in the myelin lipids. It is also abundant in the adrenal gland and kidney. AdA is not found in everyday diet but is formed from ARA by chain elongation. Similar to ARA, AdA is metabolized by COX into dihomo-PGs derivatives [55-57]. The non-enzymatic peroxidation of AdA leads to the release of dihomo-IsoP derivatives and was first reported by VanRollins et al. in 2008 [10]. The $F_{2}$-dihomo-IsoPs are present as 4 regio-isomers (7, 10, 14 or 17) in which 7 - and 17 -series are the most present in vivo. Recently, dihomo-IsoFs which can add up to 256 metabolites were discovered and quantified in pig brain samples [58].

4.2.1. $F_{2}$-dihomo-IsoPs and $F_{2}$-dihomo-IsoFs as oxidative stress biomarkers

In 2008 , the discovery of $\mathrm{F}_{2}$-dihomo-IsoPs showed in particular that the formation of $\mathrm{F}_{2}$-dihomo-IsoPs and $\mathrm{F}_{4}$-NeuroPs was of phospholipid origin and time-dependent (gray matter, white matter and myelin) [10]. The ratio of AdA/DHA in the different samples was consistent with $\mathrm{F}_{2}$-dihomo-IsoPs to NeuroPs at homeostatic conditions, but after in vitro oxidation, the myelin lipids of the white matter consistently showed highest increases compared to the gray matter (154\% vs 50\% at $24 \mathrm{~h}$ ). Furthermore, in urine of adult volunteers, $\mathrm{F}_{2}$-dihomo-IsoPs were not detected, whereas in brain tissues of Alzheimer's disease patients' frontal lobe white matter, a 2-fold higher level compared to healthy volunteers was reported.

In 2014, a novel isofuran derivative of AdA, termed dihomo-IsoF was synthesized; the compound $17(R S)-S C-\Delta^{15}-11$-dihomo-IsoF [58]; represents one of the 8 series of dihomo-IsoF (each series with its 32 potential isomers). Quantitation in brain of preterm pigs showed that, out of the isofuran derivatives of ARA, DHA and AdA, dihomo-IsoF was the highest and had level comparable to $4-\mathrm{F}_{4 \mathrm{t}}-\mathrm{NeuroPs}$ which can potentially be valuable for assessing neuronal disorders. Knowing that
AdA level was more than 10 times lower than DHA, and that both PUFAs mainly represent gray and white matter, respectively, This suggests that both dihomo-IsoFs and $4-\mathrm{F}_{4 \mathrm{t}}$-NeuroPs should be used as complementary biomarkers when evaluating neuronal damage and disease.

$\mathrm{F}_{2}$-dihomo-IsoPs were also measured in RTT patients and found to be an early disease biomarker. It was shown that these metabolites were two-orders of magnitude elevated in plasma of first stage RTT patients compared to controls [59]. These data indicate for the first time, that quantification of $\mathrm{F}_{2}$-dihomo-IsoPs in plasma can represent an early biomarker of the disease. Further research on RTT showed that 6 months of n-3 fish oil supplementation can dramatically reduce the clinical severity of the disease together with a significant decrease in all the examined oxidative stress biomarkers and mainly of $\mathrm{F}_{2}$-dihomo-IsoPs (by 82\%) [60].

\section{3. $\alpha$-Linolenic acid}

ALA is an essential fatty acid and precursor in humans of the n-3 PUFAs such as EPA and DHA. It is found in algae and higher plants, and can be highly enriched in certain oils such as linseed oil (up to $65 \%$ total fatty acid (FA). Despite being an essential FA, it is a minor component of animal tissues and mainly used for energy, elongation and desaturation to a more complex PUFA, and oxygenated by lipoxygenases. ALA can be oxidized non-enzymatically to produce oxygenated cyclic compounds known as phytoprostanes (PhytoPs). They were first described in 1998 by Mueller and Parchmann in plants [11]. Only two series can be found, the 9th and 16th series, and so far the families found in plants are the F-, D-, E-, A, deoxy-J, B- and L-PhytoPs [61-64]. PhytoPs are known to be biomarkers of oxidative stress in plants and biologically active but their impact in humans is still unknown. The only study of PhytoPs in human was conducted by Barden et al. [65] who found that supplementation of flaxseed oil (62\% of ALA, $5.4 \mathrm{~g} / \mathrm{d}$ ) increased plasma levels of $\mathrm{F}_{1}$-PhytoPs as well as plasma ALA, but to a rather low extent. It is clear that PhytoPs remain to date under-investigated, as a potential biomarker of oxidative stress and it may be limited to plants and vegetable oils.

\section{Bioactive lipids and potential signaling molecules}

The biological activities of non-enzymatic-derived cyclic oxygenated metabolites are well recognized but the focus has been mainly on IsoPs (from ARA) [66]. Of the $\mathrm{F}_{2}$-IsoPs, $15-\mathrm{F}_{2 \mathrm{t}}$-IsoP is the most studied where it is able to induce vasoconstriction and platelet activation. In addition, $\mathrm{F}_{2}$-IsoPs induces inflammation by expression of adhesion molecules (e.g. ICAM-1) leading to enhanced adhesion of monocytes, mitogenesis of smooth muscle cells and proliferation of fibroblasts. Collectively, they are all related to the pathogenesis of atherosclerosis and associated with cardiovascular diseases (see [2] for details regarding the mechanisms of action).

In contrast, the biological activities of $n-3$ derived IsoPs and NeuroP remain largely unexplored probably because of the difficulties linked to their chemical synthesis and their analysis in vivo. However, several lines of evidence in the literature showed that some peroxidized metabolites of n-3 PUFAs are bioactive molecules and substantially beneficial. The group of Sethi et al. was the first to demonstrate that peroxidation of EPA and DHA contributes to anti-inflammatory activities [67]. The authors showed that ex vivo oxidation of EPA and DHA (obtained with $\mathrm{CuSO}_{4}$ and ascorbic acid) reduced the adhesion of U937 monocytes to endothelial cells and decreased the expression of adhesion molecules whereas EPA and DHA had no effect. The nature of peroxidized metabolites from EPA and DHA was not identified at this time but the authors demonstrated that the peroxidation of EPA and DHA was a mandatory prerequisite to make them bioactive on endothelial cells. The reduction of adhesion molecules expression was later linked to the inhibition of NFKB binding activity and associated with PPAR $\gamma$ dependent mechanism [68]. Another study from the same group showed that endothelial 
cells exposed to oxidized EPA reduced the production of inflammatory cytokines (IL-8, MCP-1) [69].

The bioactivity of oxidized EPA and DHA was also investigated in hepatocytes and found to be associated with ApoB100 degradation [70] and iNOS expression [71]. Moreover, the impact of EPA and DHA on the ionic potential of cardiac function is well-defined [72] and it has been shown that this effect, at least in rat cardiac ventricular myocytes, is due to peroxidation of DHA [73]. In support, one of the oxidized DHA product, $4(R S)-4-\mathrm{F}_{4 \mathrm{t}} \mathrm{-NeuroP}$ has been recently elucidated to have cardiac anti-arrhythmic properties and potentially be a therapeutic agent [74].

Morrow and coworkers, pioneers in the in vivo identification of IsoPs and NeuroPs, were the first to speculate that EPA and DHA-related isoprostanes could be bioactive molecules involved in atherosclerosis prevention [75]. This hypothesis was more thoroughly investigated using an integrated approach associating a dose-response intervention study with DHA in LDLR $^{-/-}$mice, targeted lipidomic analysis, and unbiased statistical analysis including correlation analyses, hierarchical cluster and projection to latent structure discriminate analysis [53]. The main finding of this study was the identification of $\mathrm{F}_{4}$-NeuroPs that negatively correlated with plaque size and the best predictive variable of atherosclerosis prevention. Altogether, the results reinforced the hypothesis that $\mathrm{F}_{4}$-NeuroPs could contribute to the anti-atherogenic effects of DHA. In parallel, several in vitro experiments showed that EPA and DHA-related isoprostanes (namely $15-\mathrm{A}_{3 \mathrm{t}}-\mathrm{IsoP}, \mathrm{J}_{3}-\mathrm{IsoP}, \mathrm{A}_{4} / \mathrm{J}_{4}-$ NeuroP and $4-\mathrm{F}_{4 \mathrm{t}}$-NeuroP) possessed potent anti-inflammatory properties linked notably to the inhibition of the NFKB and/or Nrf-2 pathways [76-79]. However, contrasting outcome was found in supplementation of RTT patients with n-3 PUFA from fish oil in which plasma free $\mathrm{F}_{4}$-NeuroPs concentrations were lower when compared to controls. Also, the level of free $\mathrm{F}_{4}$-NeuroPs released was inversely associated with cardiac left ventricular systolic function in the RTT patients after fish oil supplementation $[37,60,80]$.

The biological activities of PhytoPs have been mainly demonstrated in plants. They can trigger the first adaptive responses to oxidative stress by inducing notably the expression of genes involved in detoxification and secondary metabolism [81,82]. It is evidently shown in humans, where consumption of plant food sources rich in ALA or inhalation of pollen had relatively noticeable levels of PhytoP in vivo [83,84]. However, reports on bioactivity of PhytoPs in the mammalian systems are scarce and to date, findings mainly rely on in vitro experiments, despite their occurrence has been demonstrated in vivo in humans [85]. Nevertheless, different types of PhytoPs (mainly the cyclopentenone ring structure, A-, deoxy-J-, and their precursors E- and D- expect the B-type structures) have been shown to exert potent inflammatory regulation properties illustrated by the inhibition of nitric oxide production by LPS-stimulated mice macrophages (RAW 264.7) via NFkB inhibition [83], and by the decreased dendritic cell IL-12 production and stimulation of TH2 polarization of naïve T cells [86]. Another study showed putative anti-aggregation properties of ent-16- $\mathrm{F}_{1}$-PhytoP [65]. Recently, Minghetti et al. investigated the neuroprotective effects of $\mathrm{B}_{1}$-PhytoPs, by protecting undifferentiated neuronal cells (SH-SY5Y cells) against oxidative stress induced by hydrogen peroxide, and promoting myelination [87].

\section{Conclusions}

In this review, we have discussed findings showing that nonenzymatically-derived cyclic oxygenated metabolites of n-3 and n-6 PUFA, i.e. isoprostanes, neuroprostanes, dihomo-isoprostanes and phytoprostanes can be useful oxidative stress biomarkers, especially in neuronal disorders and diseases, but can also exhibit bioactivities contributing to signaling and regulatory events in vivo. There is scope to explore how the relative prevalence of these oxygenated cyclic products of PUFA can elucidate the beneficial or detrimental effects of their precursor fatty acids in different (patho)physiological conditions.

\section{References}

[1] B. Halliwell, J.M.C. Gutteridge (Eds.), Free Radicals in Biology and Medicine, 4th ed. Oxford University Press, Oxford, United-Kingdom, 2007.

[2] U. Jahn, J.M. Galano, T. Durand, Beyond prostaglandins - chemistry and biology of cyclic oxygenated metabolites formed by free-radical pathways from polyunsaturated fatty acids, Angew. Chem. Int. Ed. 47 (2008) 5894-5955.

[3] J.D. Morrow, K.E. Hill, R.F. Burk, T.M. Nammour, K.F. Badr, L.J. Roberts, A series of prostaglandin F2-like compounds are produced in vivo in humans by a noncyclooxygenase, free radical-catalyzed mechanism, Proc. Natl. Acad. Sci. U. S. A. 87 (1990) 9383-9387.

[4] M.B. Kadiiska, B.C. Gladen, D.D. Baird, D. Germolec, L.B. Graham, C.E. Parker, A. Nyska, J.T. Wachsman, B.N. Ames, S. Basu, N. Brot, G.A. FitzGerald, R.A. Floyd, M. George, J.W. Heinecke, G.E. Hatch, K. Hensley, J.A. Lawson, L.J. Marnett, J.D. Morrow, D.M. Murray, J. Plastaras, L.J. Roberts II, J. Rokach, M.K. Shigenaga, R.S. Sohal, J. Sun, R.R. Tice, D.H. Van Thiel, D. Wellner, P.B. Walter, K.B. Tomer, R.P. Mason, J.C. Barrett, Biomarkers of oxidative stress study II: are oxidation products of lipids, proteins, and DNA markers of CCl4 poisoning? Free Radic. Biol. Med. 38 (2005) 698-710.

[5] G.L. Milne, H. Yin, K.D. Hardy, S.S. Davies, L.J. Roberts, Isoprostane generation and function, Chem. Rev. 111 (2011) 5973-5996.

[6] J.-M. Galano, E. Mas, A. Barden, T.A. Mori, C. Signorini, C. De Felice, A. Barrett, C. Opere, E. Pinot, E. Schwedhelm, R. Benndorf, J. Roy, J.-Y. Le Guennec, C. Oger, T. Durand, Isoprostanes and neuroprostanes: total synthesis, biological activity and biomarkers of oxidative stress in humans, Prostaglandins Other Lipid Mediat. 107 (2013) 95-102.

[7] J. Nourooz-Zadeh, E.H. Liu, E. Anggard, B. Halliwell, F4-isoprostanes: a novel class of prostanoids formed during peroxidation of docosahexaenoic acid (DHA), Biochem. Biophys. Res. Commun. 242 (1998) 338-344.

[8] L.J. Roberts, T.J. Montine, W.R. Markesbery, A.R. Tapper, P. Hardy, S. Chemtob, W.D. Dettbarn, J.D. Morrow, Formation of isoprostane-like compounds (neuroprostanes) in vivo from docosahexaenoic acid, J. Biol. Chem. 273 (1998) 13605-13612.

[9] J. Nourooz-Zadeh, B. Halliwell, E.E. änggård, Evidence for the formation of F3isoprostanes during peroxidation of eicosapentaenoic acid, Biochem. Biophys. Res. Commun. 236 (1997) 467-472

[10] M. VanRollins, R.L. Woltjer, H. Yin, J.D. Morrow, T.J. Montine, F2-dihomo-isoprostanes arise from free radical attack on adrenic acid, J. Lipid Res. 49 (2008) 995-1005.

[11] S. Parchmann, M.J. Mueller, Evidence for the formation of dinor isoprostanes E1 from alpha-linolenic acid in plants, J. Biol. Chem. 273 (1998) 32650-32655.

[12] N.A. Porter, M.O. Funk, Peroxy radical cyclization as a model for prostaglandin biosynthesis, J. Org. Chem. 40 (1975) 3614-3615

[13] W.A. Pryor, J.P. Stanley, Suggested mechanism for the production of malonaldehyde during the autoxidation of polyunsaturated fatty acids. Nonenzymic production of prostaglandin endoperoxides during autoxidation, J. Org. Chem. 40 (1975) 3615-3617.

[14] D.M. Stafforini, J.R. Sheller, T.S. Blackwell, A. Sapirstein, F.E. Yull, T.M. McIntyre, J.V. Bonventre, S.M. Prescott, L.J. Roberts, Release of free F2-isoprostanes from esterified phospholipids is catalyzed by intracellular and plasma platelet-activating factor acetylhydrolases, J. Biol. Chem. 281 (2006) 4616-4623.

[15] J.P. Fessel, N.A. Porter, K.P. Moore, J.R. Sheller, L.J. Roberts, Discovery of lipid peroxidation products formed in vivo with a substituted tetrahydrofuran ring (isofurans) that are favored by increased oxygen tension, Proc. Natl. Acad. Sci. 99 (2002) 16713-16718

[16] K.O. Arneson, L.J. Roberts, Measurement of products of docosahexaenoic acid peroxidation, neuroprostanes, and neurofurans, Methods Enzym. 433 (2007) 127-143.

[17] W.L. Song, J.A. Lawson, D. Reilly, J. Rokach, C.T. Chang, B. Giasson, G.A. FitzGerald, Neurofurans, novel indices of oxidant stress derived from docosahexaenoic acid, J. Biol. Chem. 283 (2008) 6-16.

[18] A. de La Torre, Y.Y. Lee, C. Oger, P.T. Sangild, T. Durand, J.C.-Y. Lee, J.-M. Galano, Synthesis, discovery, and quantitation of dihomo-isofurans: biomarkers for in vivo adrenic acid peroxidation, Angew. Chem. 126 (2014) 6363-6366.

[19] T. Durand, A. Guy, O. Henry, A. Roland, S. Bernad, S.E. Fangour, J.-P. Vidal, J.-C. Rossi, Total syntheses of iso-, neuro- and phytoprostanes: new insight in lipid chemistry, Chem. Phys. Lipids 128 (2004) 15-33.

[20] Emmanuella Jahn, Thierry Durand, J.-M. Galano, U. Jahn, Recent approaches to the total synthesis of phytoprostanes, isoprostanes and neuroprostanes as important products of lipid oxidative stress and biomarkers of disease, Chem. Listy 108 (2014) 301-319.

[21] H. Yin, E.S. Musiek, L. Gao, N.A. Porter, J.D. Morrow, Regiochemistry of neuroprostanes generated from the peroxidation of docosahexaenoic acid in vitro and in vivo, J. Biol. Chem. 280 (2005) 26600-26611.

[22] C. Vigor, J. Bertrand-Michel, E. Pinot, C. Oger, J. Vercauteren, P. Le Faouder, J.-M. Galano, J.C.-Y. Lee, T. Durand, Non-Enzymatic Lipid Oxidation Products in Biological System: Assessment of the Metabolites from Polyunsaturated Fatty Acids, J. Chromatogr. B. (n.d.).

[23] W.L. Song, G. Paschos, S. Fries, M.P. Reilly, Y. Yu, J. Rokach, C.T. Chang, P. Patel, J.A. Lawson, G.A. Fitzgerald, Novel eicosapentaenoic acid-derived F3-isoprostanes as biomarkers of lipid peroxidation, J. Biol. Chem. 284 (2009) 23636-23643.

[24] C.M. Depner, K.A. Philbrick, D.B. Jump, Docosahexaenoic acid attenuates hepatic inflammation, oxidative stress, and fibrosis without decreasing hepatosteatosis in a Ldlr $-/-$ mouse model of western diet-induced nonalcoholic steatohepatitis, J. Nutr. 143 (2013) 315-323.

[25] M.L.S. Chung, K.Y.E. Lee, C.Y.J. Lee, Profiling of oxidized lipid products of marine fish under acute oxidative stress, Food Chem. Toxicol. 53 (2013) 205-213.

[26] C.F. Labuschagne, E.C.A. Stigter, M.M.W.B. Hendriks, R. Berger, J. Rokach, H.C. Korswagen, A.B. Brenkman, Quantification of in vivo oxidative damage in Caenorhabditis elegans during aging by endogenous F3-isoprostane measurement, Aging Cell. 12 (2013) 214-223. 
[27] K.S. Leung, X. Chen, W. Zhong, A.C.H. Yu, C.-Y.J. Lee, Microbubble-mediated sonoporation amplified lipid peroxidation of Jurkat cells, Chem. Phys. Lipids 180 (2014) 53-60.

[28] J. Nourooz-Zadeh, E.H. Liu, B. Yhlen, E.E. Anggard, B. Halliwell, F4-isoprostanes as specific marker of docosahexaenoic acid peroxidation in Alzheimer's disease, J. Neurochem. 72 (1999) 734-740.

[29] Y.P. Hsieh, C.L. Lin, A.L. Shiue, H. Yin, J.D. Morrow, J.C. Hsu, T.C. Hsieh, H.J. Wei, H.C. Yen, Correlation of F4-neuroprostanes levels in cerebrospinal fluid with outcome of aneurysmal subarachnoid hemorrhage in humans, Free Radic. Biol. Med. 47 (2009) 814-824.

[30] E.E. Reich, W.R. Markesbery, L.J. Roberts II, L.L. Swift, J.D. Morrow, T.J. Montine, Brain regional quantification of F-ring and D-/E-ring isoprostanes and neuroprostanes in Alzheimer's disease, Am. J. Pathol. 158 (2001) 293-297.

[31] S.A. Back, N.L. Luo, R.A. Mallinson, J.P. O'Malley, L.D. Wallen, B. Frei, J.D. Morrow, C.K. Petito, C.T. Roberts, G.H. Murdoch, T.J. Montine, Selective vulnerability of preterm white matter to oxidative damage defined by F2-isoprostanes, Ann. Neurol. 58 (2005) 108-120.

[32] T.J. Montine, K.S. Montine, W. McMahan, W.R. Markesbery, J.F. Quinn, J.D. Morrow, F2-isoprostanes in Alzheimer and other neurodegenerative diseases, Antioxid. Redox Signal. 7 (2005) 269-275.

[33] Z. Korade, L. Xu, K. Mirnics, N.A. Porter, Lipid biomarkers of oxidative stress in a genetic mouse model of Smith-Lemli-Opitz syndrome, J. Inherit. Metab. Dis. 36 (2013) 113-122.

[34] C. De Felice, F. Della Ragione, C. Signorini, S. Leoncini, A. Pecorelli, L. Ciccoli, F. Scalabrì, F. Marracino, M. Madonna, G. Belmonte, L. Ricceri, B. De Filippis, G. Laviola, G. Valacchi, T. Durand, J.-M. Galano, C. Oger, A. Guy, V. Bultel-Poncé, J. Guy, S. Filosa, J. Hayek, M. D'Esposito, Oxidative brain damage in Mecp2-mutant murine models of Rett syndrome, Neurobiol. Dis. 68 (2014) 66-77.

[35] R. Solberg, M. Longini, F. Proietti, P. Vezzosi, O.D. Saugstad, G. Buonocore, Resuscitation with supplementary oxygen induces oxidative injury in the cerebral cortex, Free Radic. Biol. Med. 53 (2012) 1061-1067.

[36] R.C. Seet, C.Y. Lee, E.C. Lim, J.J. Tan, A.M. Quek, W.L. Chong, W.F. Looi, S.H. Huang, H. Wang, Y.H. Chan, B. Halliwell, Oxidative damage in Parkinson disease: measurement using accurate biomarkers, Free Radic. Biol. Med. 48 (2010) 560-566.

[37] C. Signorini, C. De Felice, S. Leoncini, A. Giardini, M. D'Esposito, S. Filosa, F. Della Ragione, M. Rossi, A. Pecorelli, G. Valacchi, L. Ciccoli, J. Hayek, F4-neuroprostanes mediate neurological severity in Rett syndrome, Clin. Chim. Acta 412 (2011) 1399-1406.

[38] R.C.S. Seet, C.-Y.J. Lee, B.P.L. Chan, V.K. Sharma, H.-L. Teoh, N. Venketasubramanian, E.C.H. Lim, W.-L. Chong, W.-F. Looi, S.-H. Huang, B.K.C. Ong, B. Halliwell, Oxidative damage in ischemic stroke revealed using multiple biomarkers, Stroke 42 (2011) 2326-2329.

[39] R.C. Seet, C.Y. Lee, W.M. Loke, S.H. Huang, H. Huang, W.F. Looi, E.S. Chew, A.M. Quek, E.C. Lim, B. Halliwell, Biomarkers of oxidative damage in cigarette smokers: which biomarkers might reflect acute versus chronic oxidative stress? Free Radic. Biol. Med. 50 (2011) 1787-1793.

[40] A.E. Barden, T.B. Corcoran, E. Mas, T. Durand, J.-M. Galano, L.J. Roberts, M. Paech, N.A. Muchatuta, M. Phillips, T.A. Mori, Is there a role for isofurans and neuroprostanes in pre-eclampsia and normal pregnancy? Antioxid. Redox Signal. 16 (2012) 165-169.

[41] M. Ng, J. Lee, W.M. Loke, L. Yeo, A. Quek, E.C. Lim, B. HALLIWELL, R.C.S. Seet, Does influenza A infection increase oxidative damage? Antioxid. Redox Signal. 21 (2004) 1025-1031.

[42] T.J. Montine, J.F. Quinn, D. Milatovic, L.C. Silbert, T. Dang, S. Sanchez, E. Terry, L.J. Roberts, J.A. Kaye, J.D. Morrow, Peripheral F2-isoprostanes and F4-neuroprostanes are not increased in Alzheimer's disease, Ann. Neurol. 52 (2002) 175-179.

[43] D. Milatovic, S. Zaja-Milatovic, K.S. Montine, P.J. Horner, T.J. Montine, Pharmacologic suppression of neuronal oxidative damage and dendritic degeneration following direct activation of glial innate immunity in mouse cerebrum, J. Neurochem. 87 (2003) 1518-1526.

[44] D. Milatovic, M. VanRollins, K. Li, K.S. Montine, T.J. Montine, Suppression of murine cerebral F2-isoprostanes and F4-neuroprostanes from excitotoxicity and innate immune response in vivo by $\alpha$ - or $\gamma$-tocopherol, J. Chromatogr. B 827 (2005) 88-93.

[45] S. Zaja-Milatovic, R.C. Gupta, M. Aschner, T.J. Montine, D. Milatovic, Pharmacologic suppression of oxidative damage and dendritic degeneration following kainic acid-induced excitotoxicity in mouse cerebrum, NeuroToxicology 29 (2008) 621-627.

[46] J.F. Quinn, J.R. Bussiere, R.S. Hammond, T.J. Montine, E. Henson, R.E. Jones, R.W. Stackman Jr., Chronic dietary $\alpha$-lipoic acid reduces deficits in hippocampal memory of aged Tg2576 mice, Neurobiol. Aging 28 (2007) 213-225.

[47] W. Balduini, S. Carloni, S. Perrone, S. Bertrando, M.L. Tataranno, S. Negro, F. Proietti, M. Longini, G. Buonocore, The use of melatonin in hypoxic-ischemic brain damage: an experimental study, J. Matern. Fetal Neonatal Med. 25 (2012) 119-124.

[48] Y. Zhang, D. Milatovic, M. Aschner, P.J. Feustel, H.K. Kimelberg, Neuroprotection by tamoxifen in focal cerebral ischemia is not mediated by an agonist action at estrogen receptors but is associated with antioxidant activity, Exp. Neurol. 204 (2007) 819-827.

[49] S.E. Browne, L.J. Roberts II, P.A. Dennery, S.R. Doctrow, M.F. Beal, C. Barlow, R.L Levine, Treatment with a catalytic antioxidant corrects the neurobehavioral defect in ataxia-telangiectasia mice, Free Radic. Biol. Med. 36 (2004) 938-942.

[50] D.R. Euston, A.J. Gruber, B.L. McNaughton, The role of medial prefrontal cortex in memory and decision making, Neuron 76 (2012) 1057-1070.

[51] A.C. Andreazza, J.-F. Wang, F. Salmasi, L. Shao, L.T. Young, Specific subcellular changes in oxidative stress in prefrontal cortex from patients with bipolar disorder, J. Neurochem. 127 (2013) 552-561.

[52] J.D. Morrow, J.A. Awad, T. Kato, K. Takahashi, K.F. Badr, L.J. Roberts, R.F. Burk, Formation of novel non-cyclooxygenase-derived prostanoids (F2-isoprostanes) in carbon tetrachloride hepatotoxicity. An animal model of lipid peroxidation, J. Clin. Invest. 90 (1992) 2502-2507.
[53] C. Gladine, J.W. Newman, T. Durand, T.L. Pedersen, J.-M. Galano, C. Demougeot, O. Berdeaux, E. Pujos-Guillot, A. Mazur, B. Comte, Lipid profiling following intake of the omega 3 fatty acid DHA identifies the peroxidized metabolites f4-neuroprostanes as the best predictors of atherosclerosis prevention, PLoS One 9 (2014) e89393.

[54] T.A. Mori, R.J. Woodman, V. Burke, I.B. Puddey, K.D. Croft, L.J. Beilin, Effect of eicosapentaenoic acid and docosahexaenoic acid on oxidative stress and inflammatory markers in treated-hypertensive type 2 diabetic subjects, Free Radic. Biol. Med. 35 (2003) 772-781.

[55] L.D. Tobias, F.M. Vane, J.R. Paulsrud, The biosynthesis of 1a,1b-dihomo-PGE2 and 1a,1b-dihomo-PGF2 $\alpha$ from 7,10,13,16-docosatetraenoic acid by an acetonepentane powder of sheep vesicular gland microsomes, Prostaglandins 10 (1975) 443-468.

[56] H. Sprecher, M. VanRollins, F. Sun, A. Wyche, P. Needleman, Dihomo-prostaglandins and -thromboxane. A prostaglandin family from adrenic acid that may be preferentially synthesized in the kidney, J. Biol. Chem. 257 (1982) 3912-3918.

[57] W.B. Campbell, J.R. Falck, J.R. Okita, A.R. Johnson, K.S. Callahan, Synthesis of dihomoprostaglandins from adrenic acid (7,10,13,16-docosatetraenoic acid) by human endothelial cells, Biochim. Biophys. Acta BBA - Lipids Lipid Metab. 837 (1985) 67-76.

[58] A. De La Torre, Y.Y. Lee, C. Oger, P.T. Sangild, T. Durand, C.Y.J. Lee, J.-M. Galano Synthesis, discovery and quantitation of dihomo-isofurans: novel biomarkers of in vivo adrenic acid peroxidation, Angew. Chem. Int. Ed. (2014), http://dx.doi.org/ 10.1002/anie.201402440R1 (in press).

[59] C. De Felice, C. Signorini, T. Durand, C. Oger, A. Guy, V. Bultel-Poncé, J.-M. Galano, L. Ciccoli, S. Leoncini, M. D'Esposito, S. Filosa, A. Pecorelli, G. Valacchi, J. Hayek, F2-dihomo-isoprostanes as potential early biomarkers of lipid oxidative damage in Rett syndrome, J. Lipid Res. 52 (2011) 2287-2297.

[60] C. De Felice, C. Signorini, T. Durand, L. Ciccoli, S. Leoncini, M. D'Esposito, S. Filosa, C. Oger, A. Guy, V. Bultel-Poncé, J.-M. Galano, A. Pecorelli, L. De Felice, G. Valacchi, J. Hayek, Partial rescue of Rett syndrome by $\omega-3$ polyunsaturated fatty acids (PUFAs) oil, Genes Nutr. 7 (2012) 447-458.

[61] R. Imbusch, M.J. Mueller, Analysis of oxidative stress and wound-inducible dinor isoprostanes F1 (phytoprostanes F1) in plants, Plant Physiol. 124 (2000) 1293-1304

[62] R. Imbusch, M.J. Mueller, Formation of isoprostane F(2)-like compounds (phytoprostanes $F(1)$ ) from alpha-linolenic acid in plants, Free Radic. Biol. Med 28 (2000) 720-726.

[63] I. Thoma, C. Loeffler, A.K. Sinha, M. Gupta, M. Krischke, B. Steffan, T. Roitsch, M.J. Mueller, Cyclopentenone isoprostanes induced by reactive oxygen species trigger defense gene activation and phytoalexin accumulation in plants, Plant J. 34 (2003) 363-375.

[64] C. Loeffler, S. Berger, A. Guy, T. Durand, G. Bringmann, M. Dreyer, U. von Rad, J. Durner, M.J. Mueller, B1-phytoprostanes trigger plant defense and detoxification responses, Plant Physiol. 137 (2005) 328-340.

[65] A.E. Barden, K.D. Croft, T. Durand, A. Guy, M.J. Mueller, T.A. Mori, Flaxseed oil supplementation increases plasma F1-phytoprostanes in healthy men, J. Nutr. 139 (2009) 1890-1895.

[66] L.J. Roberts, G.L. Milne, Isoprostanes, J. Lipid Res. 50 (2009) S219-S223.

[67] S. Sethi, A.Y. Eastman, J.W. Eaton, Inhibition of phagocyte-endothelium interactions by oxidized fatty acids: a natural anti-inflammatory mechanism? J. Lab. Clin. Med. 128 (1996) 27-38.

[68] S. Sethi, O. Ziouzenkova, H. Ni, D.D. Wagner, J. Plutzky, T.N. Mayadas, Oxidized omega-3 fatty acids in fish oil inhibit leukocyte-endothelial interactions through activation of PPAR $\alpha$, Blood 100 (2002) 1340-1346.

[69] A. Mishra, A. Chaudhary, S. Sethi, Oxidized omega-3 fatty acids inhibit NF- $\kappa B$ activation via a PPAR $\alpha$-dependent pathway, Arterioscler. Thromb. Vasc. Biol. 24 (2004) 1621-1627.

[70] M. Pan, A.I. Cederbaum, Y.-L. Zhang, H.N. Ginsberg, K.J. Williams, E.A. Fisher, Lipid peroxidation and oxidant stress regulate hepatic apolipoprotein B degradation and VLDL production, J. Clin. Invest. 113 (2004) 1277-1287.

[71] Y. Araki, M. Matsumiya, T. Matsuura, M. Oishi, M. Kaibori, T. Okumura, M. Nishizawa, H. Takada, A.-H. Kwon, Peroxidation of n-3 polyunsaturated fatty acids inhibits the induction of iNOS gene expression in proinflammatory cytokine-stimulated hepatocytes, J. Nutr. Metab. 2011 (2011) e374542.

[72] A. Leaf, Y.-F. Xiao, J.X. Kang, G.E. Billman, Prevention of sudden cardiac death by $n-3$ polyunsaturated fatty acids, Pharmacol. Ther. 98 (2003) 355-377.

[73] S. Judé, S. Bedut, S. Roger, M. Pinault, P. Champeroux, E. White, J.-Y. Le Guennec Peroxidation of docosahexaenoic acid is responsible for its effects on ITO and ISS in rat ventricular myocytes, Br. J. Pharmacol. 139 (2003) 816-822.

[74] Le Guennec, J.-.Y, Galano, J.-M., Oger, Camille, Thireau, J, Roy, J, Bultel-Poncé, V, Guy A, Durand, T, Methods and pharmaceutical composition for the treatment and prevention of cardiac arrhythmias, PCT 4 December 2013-PCT/EP2013/07546, n.d.

[75] V. Saraswathi, L. Gao, J.D. Morrow, A. Chait, K.D. Niswender, A.H. Hasty, Fish oil increases cholesterol storage in white adipose tissue with concomitant decreases in inflammation, hepatic steatosis, and atherosclerosis in mice, J. Nutr. 137 (2007) 1776-1782.

[76] L. Gao, J. Wang, K.R. Sekhar, H. Yin, N.F. Yared, S.N. Schneider, S. Sasi, T.P. Dalton, M.E Anderson, J.Y. Chan, J.D. Morrow, M.L. Freeman, Novel n-3 fatty acid oxidation products activate Nrf2 by destabilizing the association between Keap1 and Cullin3, J. Biol. Chem. 282 (2007) 2529-2537.

[77] E.S. Musiek, L. Gao, G.L. Milne, W. Han, M.B. Everhart, D. Wang, M.G. Backlund, R.N DuBois, G. Zanoni, G. Vidari, T.S. Blackwell, J.D. Morrow, Cyclopentenone isoprostanes inhibit the inflammatory response in macrophages, J. Biol. Chem. 280 (2005) 35562-35570.

[78] J.D. Brooks, E.S. Musiek, T.R. Koestner, J.N. Stankowski, J.R. Howard, E.M. Brunoldi, A Porta, G. Zanoni, G. Vidari, J.D. Morrow, G.L. Milne, B. McLaughlin, The fatty acid 
oxidation product 15-A3t-Isoprostane is a potent inhibitor of NFkB transcription and macrophage transformation, J. Neurochem. 119 (2011) 604-616.

[79] Z. Majkova, J. Layne, M. Sunkara, A.J. Morris, M. Toborek, B. Hennig, Omega-3 fatty acid oxidation products prevent vascular endothelial cell activation by coplanar polychlorinated biphenyls, Toxicol. Appl. Pharmacol. 251 (2011) 41-49.

[80] S. Maffei, C. De Felice, P. Cannarile, S. Leoncini, C. Signorini, A. Pecorelli, B. Montomoli, S. Lunghetti, L. Ciccoli, T. Durand, R. Favilli, J. Hayek, Effects of omega3 PUFAs supplementation on myocardial function and oxidative stress markers in typical Rett syndrome, Mediat. Inflamm. 2014 (2014).

[81] M.J. Mueller, Archetype signals in plants: the phytoprostanes, Curr. Opin. Plant Biol. 7 (2004) 441-448.

[82] T. Durand, V. Bultel-Ponce, A. Guy, S. El Fangour, J.C. Rossi, J.M. Galano, Isoprostanes and phytoprostanes: bioactive lipids, Biochimie 93 (2011) 52-60.

[83] K. Karg, V.M. Dirsch, A.M. Vollmar, J.L. Cracowski, F. Laporte, M.J. Mueller, Biologically active oxidized lipids (phytoprostanes) in the plant diet and parenteral lipid nutrition, Free Radic. Res. 41 (2007) 25-37.

[84] C. Traidl-Hoffmann, V. Mariani, H. Hochrein, K. Karg, H. Wagner, J. Ring, M.J. Mueller T. Jakob, H. Behrendt, Pollen-associated phytoprostanes inhibit dendritic cell interleukin-12 production and augment T helper type 2 cell polarization, J. Exp. Med. 201 (2005) 627-636.

[85] A. Barden, E. Mas, P. Henry, T. Durand, J-M. Galano, LJ. Roberts, K.D. Croft, T.A. Mori The effects of oxidation products of arachidonic acid and $\mathrm{n} 3$ fatty acids on vascular and platelet function, Free Radic. Res. 45 (2011) 469-476.

[86] S. Gilles, V. Mariani, M. Bryce, M.J. Mueller, J. Ring, T. Jakob, S. Pastore, H. Behrendt, C. Traidl-Hoffmann, Pollen-derived E1-phytoprostanes signal via PPAR- $\gamma$ and NF-kBdependent mechanisms, J. Immunol. 182 (2009) 6653-6658.

[87] L. Minghetti, R. Salvi, M. Lavinia Salvatori, M. Antonietta Ajmone-Cat, C. De Nuccio, S Visentin, V. Bultel-Poncé, C. Oger, A. Guy, J.-M. Galano, A. Greco, A. Bernardo, T. Durand, Nonenzymatic oxygenated metabolites of $\alpha$-linolenic acid B1- and L1-phytoprostanes protect immature neurons from oxidant injury and promote differentiation of oligodendrocyte progenitors through PPAR- $\gamma$ activation, Free Radic. Biol. Med. 73 (2014) 41-50.

[88] J.A. Lawson, S. Kim, W.S. Powell, G.A. FitzGerald, J. Rokach, Oxidized derivatives of omega-3 fatty acids: identification of IPF3 alpha-VI in human urine, J. Lipid Res. 47 (2006) 2515-2524
[89] T.B. Corcoran, E. Mas, A. Barden, T. Durand, J.M. Galano, L.J. Roberts, M. Phillips, K.M. Ho, T.A. Mori, Are isofurans and neuroprostanes increased after subarachnoid hemorrhage and traumatic brain injury? Antioxid. Redox Signal. 15 (2011) 2663-2667.

[90] H.-C. Yen, H.-J. Wei, T.-W. Chen, Analytical variables affecting analysis of $\mathrm{F}_{2}$-isoprostanes and $\mathrm{F}_{4}$-neuroprostanes in human cerebrospinal fluid by gas chromatography/mass spectrometry, BioMed. Res. Int. 2013 (2013).

[91] W.R. Markesbery, R.J. Kryscio, M.A. Lovell, J.D. Morrow, Lipid peroxidation is an early event in the brain in amnestic mild cognitive impairment, Ann. Neurol. 58 (2005) 730-735.

[92] R.C.S. Seet, C.-Y.J. Lee, E.C.H. Lim, A.M.L. Quek, H. Huang, S.H. Huang, W.F. Looi, L.H. Long, B. Halliwell, Oral zinc supplementation does not improve oxidative stress or vascular function in patients with type 2 diabetes with normal zinc levels, Atherosclerosis 219 (2011) 231-239.

[93] G.L. Milne, J.D. Morrow, M.J. Picklo Sr., Elevated oxidation of docosahexaenoic acid, 22:6 (n-3), in brain regions of rats undergoing ethanol withdrawal, Neurosci. Lett. 405 (2006) 172-174.

[94] R.C. Gupta, S. Milatovic, W.-D. Dettbarn, M. Aschner, D. Milatovic, Neuronal oxidative injury and dendritic damage induced by carbofuran: protection by memantine, Toxicol. Appl. Pharmacol. 219 (2007) 97-105.

[95] D. Santos, D. Milatovic, V. Andrade, M.C. Batoreu, M. Aschner, A.P. Marreilha dos Santos, The inhibitory effect of manganese on acetylcholinesterase activity enhances oxidative stress and neuroinflammation in the rat brain, Toxicology 292 (2012) 90-98.

[96] D. Milatovic, Y. Zhang, S.J. Olson, K.S. Montine, L.J. Roberts, J.D. Morrow, T.J. Montine, T.S. Dermody, T. Valyi-Nagy, Herpes simplex virus type 1 encephalitis is associated with elevated levels of F2-isoprostanes and F4-neuroprostanes, J. Neurovirol. 8 (2002) 295-305.

[97] S.L. Cuddihy, S.S. Ali, E.S. Musiek, J. Lucero, S.J. Kopp, J.D. Morrow, L.L. Dugan, Prolonged $\alpha$-tocopherol deficiency decreases oxidative stress and unmasks $\alpha$-tocopherol-dependent regulation of mitochondrial function in the brain, J. Biol. Chem. 283 (2008) 6915-6924.

[98] F.E. Harrison, S.S. Yu, K.L. Van Den Bossche, L. Li, J.M. May, M.P. McDonald, Elevated oxidative stress and sensorimotor deficits but normal cognition in mice that cannot synthesize ascorbic acid, J. Neurochem. 106 (2008) 1198-1208.

[99] F.e. Harrison, J. Allard, R. Bixler, C. Usoh, L. Li, J.m. May, M.p. McDonald, Antioxidants and cognitive training interact to affect oxidative stress and memory in APP/PSEN1 mice, Nutr. Neurosci. 12 (2009) 203-218. 